\title{
Examination of the Relationship between Luxury Value Perception and Shopping Motivations: Turkey Sample
}

\author{
Aysel Kurnaz ${ }^{1}$ \\ ${ }^{1}$ Bursa, Turkey \\ Correspondence: Aysel Kurnaz, Bursa, Turkey. E-mail: aysel-kurnaz@hotmail.com
}

Received: August 7, 2017 Accepted: September 4, $2017 \quad$ Online Published: September 30, 2017

doi:10.5539/ijms.v9n5p108 URL: http://doi.org/10.5539/ijms.v9n5p108

\begin{abstract}
It was aimed to reveal the effects of financial, functional, individual and social value perceptions on hedonic and utilitarian shopping motivations within this study. In this direction, a questionnaire was conducted to people over the age of 18 in cities representing 12 regions of Turkey and 2857 questionnaires were put into consideration in total. Confirmatory factor analysis and structural equation modelling (SEM) were applied to data. According to findings it was identified that the luxury value perception has influence over hedonic and utilitarian motivations. The individual value dimension of luxury perception has the highest effect on hedonic motivations and social, financial and functional value dimensions follow it respectively. And the relative effect of functional luxury value perception also has the highest effect on utilitarian motivations and the financial, individual and social values follow respectively. It was found that, while all these perception's effects have positive impacts, only the social value perception has a negative impact on utilitarian motivations.
\end{abstract}

Keywords: luxury, luxury value perception, hedonic and utilitarian shopping motivations, Turkey

\section{Introduction}

In the last decade, the luxury market has become a significant object of consumption by achieving an important growth. In particular, luxury product has given shape to the whole consumption culture by setting new trends through brands (Vigneron \& Johnson, 1999, 2004). It is known that the luxury goods market has the fastest and the most profitable growth potential (Berthon et al., 2009). It has been long known that marketing of luxury goods has the fastest and the most profitable growing potential (Berthon et al., 2009). According to "Luxury goods worldwide market study, fall-winter 2016 report" published as 15 th edition by Bain \& company consulting company, luxury goods market has reached to 1,08 trillion Euro by providing a growth of $4 \%$ compared to the previous year. The appetency of consumers towards luxury goods in developing countries such as China, India, Brazil, Turkey has become the reason of this steady growth (Carlson, 2009; Leahy \& Betts, 2010; Shukla, 2010; Tynan et al., 2010). Hence, the questions that how consumers perceive luxury concept and what they consider as luxurious good have great importance (Turunen, 2015).

Along with its usage of representing the products, services or a specific life style, its being disguised into many various forms for many different people and its being based on consumers' perception which depends on their experiences and mood, transform luxury concept into a complex, flexible and abstract notion (Kapferer, 1998; Cornell, 2002; Vigneron \& Johnson, 2004). The things that are seen as luxury today may be seen as a need in the future by the change of the meaning of luxury according to time period and place (Turunen, 2015; Nwankwo et al., 2014). Therefore, it is extremely important to develop an integrative understanding by considering subjective and multidimensional structure of luxury term (Wiedmann et al., 2007).

It is seen that there are significant number of studies that approach the luxury concept from various aspects when marketing literature is examined at the stage of developing a profound understanding to luxury. Lately, luxury goods industry has become the focus of many academic studies that have taken luxury terms relating to consumer perception and buying behavior (Vigneron \& Johnson, 1999; Phau \& Prendergrast, 2000; Tsai, 2005; Wiedmann et al., 2007; Hennigs et al., 2012). Aforementioned studies have become more meaningful when different consumer groups that have different perceptions about luxury values were taken into consideration (Wiedmann et al., 2007). Moreover in the global context it is critically important that luxury researchers and marketers examine why consumers buy luxury goods, what they consider as luxury and how these value perception affect the purchase behavior by also taking cultural effects in order to overcome the difficulties that 
are occurring when identifying and estimating consumers' general needs and desire (Hennigs et al., 2012).

This paper aims to develop an understanding towards luxury consumers by detecting which of individual's shopping motivations are affected by the luxury perceptions. In this way, the results of this study are expected to provide some important clues to both researchers and marketers about the relationship between the motivations as the previous step before behavior and luxury perception.

\section{Conceptual Background}

\subsection{The Concept of Luxury}

Although the history of luxury dates back to civilization era, it was seen that negative meanings are ascribed to the concept of luxury until the 17th century (Berry, 1994). As from the $18^{\text {th }}$ century and following periods, negative expressions were replaced with a concept that makes life more comfortable and that is mostly associated with bourgeoisie society (Brun \& Castelli, 2013). The concept of luxury has been seen as unique, infrequent and only can be reached by elite minority in the history (Hauck \& Stanforth, 2007). By the $19^{\text {th }}$ century, luxury goods have become demanded by every segment of society, reaching more varieties with globalization, variations of social structure of the society, developments in industry and technology (Brun \& Castelli, 2013). In our time, luxury has become a brand that is dominated by dreams, images and signs that are beyond the material and artisans (Berthon et al., 2009).

One of the most basic descriptions about the luxury is defined by Sekora as "anything unneeded" when the approaches to the term of luxury are examined related to the concept (1977, p. 25). Vigneron \& Johnson (2004, p. 486) who defined "luxury as something beyond any functional utility where the simple use or display of particular luxury product brings esteem to the consumer". Dubois \& Duquesne (1993, p. 43) emphasize "luxury is motivated by a desire to impress others, with the ability to pay particularly high prices, this form of consumption is primarily concerned with the ostentatious display of wealth" and drawn attention to financial aspect of luxury. As for Vickers \& Renand (2003, p. 459) defined the concept as "luxury is symbols of personal and social identity" by signing emotional side of it.

Deep approaches towards to the concept of luxury arose from the definition of "conspicuous consumption" added to the literature by Thorstein Veblen. Veblen covers the concept of the consumption with economic dimension besides its social dimension with the study of "the theory of the leisure class" (1899). The concept of conspicuous consumption is built on individuals consuming luxury goods and services in a conspicuous style while sending signals about their relative status to the others (Veblen, 2005, p. 45). Veblen asserted that individuals desire a status and these status can be increased by exhibiting this wealth perceptibly (Bagwell \& Bernheim, 1996).

With the help of definitions, it is seen that the concept of luxury depends on the perception of consumer (Vigneron \& Johnson, 2004) therefore; it has to be approached from multi-directional perspectives like economical, functional, social and behavioral psychology. In recent years the reason why people buy luxury products, value-based luxury perceptions and the basic incentive factors are emphasized in studies when explaining luxury concept (Nwankwo et al., 2014; Shukla, 2012; Shukla \& Purani, 2012; Hennigs et al., 2012; Li et al., 2012; Souiden et al., 2011: Sun, 2011; Tynan et al., 2010; Berthon et al., 2009; Vigneron \& Johnson, 2004; Vickers \& Renand, 2003). The dimensions of luxury value stand as functional, experimental, symbolic, financial, individual, social, and utilitarian in the aforementioned studies.

In this study, the model developed by Wiedmann et al. (2009) was used which provides a scale that approaches luxury perception in a comprehensive and value-based luxury way. According to this model, luxury value is expressed with four dimensions; financial, functional, individual and social, and each of these dimensions have various subscales. At the same time, each of these value dimensions has an interaction with each other. Financial value perception is directly related to monetary aspects that refer individuals' renounces to achieve a luxury product, service or brand. Functional value dimension includes the subscales of luxury like usability, quality and uniqueness by emphasizing financial interest that will be gained out of a product. In this dimension, when high performance and quality are expected from a luxury product, its value also increases with its being assumed as unique. Individual value dimension includes individuals' perceptions about luxury products and it consists of self-identity, hedonic and materialist subscales (Wiedmann et al., 2007). It was observed that consumers utilise luxury products to emphasize their identities under sub-identity value (Phau \& Cheang, 2009). Luxury items contain emotional value, and when consumers perceive a product to be exquisite, glamorous and stunning, it creates a hedonistic experience for the owner and attributes the luxury product personal meanings (Turunen \& Laaksonen, 2011, p. 469). As to materialist oriented consumers they do more act consuming and make this with unique luxury products that provide status (Lynn \& Haris, 1997). Finally, social dimension of luxury includes 
conspicuous and prestige subclasses and it is seen that under this dimension individuals enhance their status by flaunting or including themselves into this group through the prestige of a luxury product (Wiedmann et al., 2009).

\subsection{Shopping Motivations}

Researchers and marketers seek a way to turn consumers' attitudes into meaningful components (Crowley et al., 1992). At this point, the studies that reveal the importance of the fact that motivations are determiners of consumers' purchase decisions and these motivations affect the various side of consumer behavior just like the products and brand evaluation (Aaker \& Lee, 2006; Yeo \& Park, 2006).

Even there are various motivations for consumers to purchase depending on their aims (Westbrook \& Black, 1985), it is widely known that many products satisfy the two important needs as hedonic and utilitarian (Batra \& Ahtola, 1991). This conceptual approach is originated from the study of Hirschman and Holbrook "the experiential aspect of consumption" (1982). In this study, it is revealed that the consumer motivations upon product categories are two dimensional in a natural way (Crowley et al., 1992). Latter studies about the concept progressed upon scale development issue. Babin et al. (1994) enhanced a scale devoted to both hedonic and utilitarian shopping motivations gathered from consumption experience. It was put forth that different hedonic and utilitarian shopping motivations exist and they are related to some important consuming variables (Ryu et al., 2010). Arnold \& Reynolds (2003) also developed a multi-dimensional scale towards shopping motivations with a different approach.

Most of the initial studies had focused on the utilitarian motivations of shopping (Babin et al., 1994; Batra \& Ahtola, 1991). It was started to give an importance to hedonic motivations too with the realization of potential importance of consumers' increasing fun and emotional value by assuming that the explanations about utilitarian based product acquiring do not reflect consumer behavior (Arnold \& Reynolds, 2003). It is also seen in the recent studies focus on hedonic and utilitarian motivations within the shopping and purchasing process (Babin and Attaway, 2000; Babin \& Babin, 2001; Arnold \& Reynolds, 2003; Stoel et al., 2004).

Utilitarian shopping motivations is defined as "target-oriented consumption" because of the desire to implement a functional assignment or meet a basic need (Babin et al., 1994). The effectiveness of shopping process is extremely important in utilitarian shopping motivation (Jones et al., 2006). Consumers who act with utilitarian motivations can perform product selection in an easier way in accordance with utility and aim (Okada, 2005). Hereby, they tend towards purchasing the product that supplies their aims in an efficient way in the shortest time (Sherry, 1990). Moreover, consumers having a utilitarian view make their evaluations cognitively and functionally (Ryu et al., 2010). Voss et al. (2003) emphasizes that utilitarian consumption addresses individual's mind and logic. Fischer and Arnold (1990) describe utilitarian consumers that see shopping as a job, as problematic consumers facing with "dark side of the shopping" in their study.

Hedonic shopping motivations are more subjective because they are motivated with pleasure, fantasy, amusement and based on desires (Hirschman \& Holbrook, 1982). Besides that, these feelings generally arouse guilt feelings. When valid reasons are found towards consumption, consumers' tendency to consume hedonic products will be higher (Crowley et al., 1992). According to Roy \& Sharon, (2012) while hedonic product consumption is related to consumers' feelings about the products, and consumers' multiple senses become prominent. Therefore this consumption is more effective in life. Consumers who act with hedonic motivation are described as "fun side of the shopping" in the literature (Fischer \& Arnold, 1990; Sherry, 1990).

It is seen that hedonic shopping motivations are explained with many dimensions in the literature but lately one of the most accepted studies belongs to Arnould \& Reynolds (2003). Hedonic motivations can be classified under 6 dimensions as motivations, adventure, value, idea, social, gratification and role according to them. Adventure dimension includes excitement and enthusiasm in shopping process; value includes pleasure of feeling in a race by buying discounted products; idea includes collecting information to be informed about the new products by keeping with the fashion; social includes consumers' spending time with their social environment by means of shopping experience; gratification involves heading towards shopping by escaping from stress to relax, and ultimately role dimension includes feelings about making others happy.

\section{Theoretical Framework}

Besides the definitions that are expressed with reference to the features of the term in the luxury literature, there exist various approaches from a different viewpoint trying to explain this term with the need concept on the basis of "consumption" and "sociology". One of these approaches belongs to famous sociologists Werner Sombart. According to Sombart, luxury is "each type of additional expenses more than essential need". At that point, it is 
useful to check the meaning of need concept. Necessity is literally related to tension caused by the absence of anything in general terms (Siegel, 1996). Because dissatisfying people's needs can harm people physiologically and psychologically, people try to satisfy these needs consciously and instinctively in many ways (Koç, 2012, p. 57). The biggest problem here is how to detect "basic need" due to its being a relative concept. Sombart asserts that it is possible with two ways. When the first one depends on ethic, esthetic and any other standard of judgement with a subjective approach, the other one is only possible with finding an objective criterion that we can measure the need. This kind of measure can be composed of individuals' physiological or cultural natural requirements. The issue of what are these requirements consists of the selection of individuals (Sombart, 2013, p. 117).

It is known that needs activate, in other words motivate the consumers (Antonides \& Van Raaij, 1998). The longer the time that a need is not met and the more important to meet that need for that person, the motivation of that need becomes that intensive (Koç, 2012, p. 199).

According to, one of these motivation theories, Abraham Maslow's "Hierarchy of needs", in order to understand how individuals are motivated one has to know their needs. With reference to this approach, Maslow investigated human needs in 5 stages hierarchically. These are physiological needs like eating-drinking, shelter; safety needs to beware of danger, social needs like love, being loved and friendship; self-esteem need including being respected, being different and status; self-actualization needs like belief, self-confidence. According to this theory, an individual can think of the latter need if only the first need is satisfied (Maslow, 1970).

According to David Mc. Clelland's "Theory of needs", one of the other motivation theories, it is possible to talk about three kind of needs as "achievement, power and affiliation". When overcoming challenges, facing with uncertainty situations come into prominence in achievement need (Mc. Clelland, 1961), it is seen that it is extremely important to impress other people and display powerful behaviors that can be effective over other people in power need (Apospori et al., 2005). The desire of an individual to become a part of a group with the sense of belonging and be in good relationships with them derives from affiliation need.

It is known from the literature that besides luxury products are defined as goods that bring prestige to its owner (Grossman \& Shapiro, 1988), possessing luxury products brings power and success, represents status (Eastman et al., 1999), and enable consumers to be a part of a group so that they feel themselves exclusive (Vigneron \& Johnson, 1999). The importance of having luxury products cannot be ignored at the process of Mc. Chelland's satisfying the power and affiliation needs and social and esteem needs in Maslow's theory. Because consumers find opportunities to express themselves by using luxury in order to emphasize or improve their identities, it can be said that this is helpful to fulfill the need stands at the last part of Maslow's hierarchy.

\section{Research Model and Hypotheses}

The concept of consumption is an expression way of social classes according to Bocock (2005, p. 84). Individuals in different social classes constitute their political, social and personal identities by assigning various meanings to products with prestige, indicator, symbol and images. Baudrillard (2004, p. 154) states that individuals in today's society prefer to buy consumption goods that they believe bringing prestige and exclusivity in order to display them. In a similar way, Bourdie aims to reveal how consumers use various consumption products or services to make explicit different life styles on the basis of social economic class and to distinguish themselves from the others by emphasizing symbols and indicators (Bocock, 2005, p. 68). When Guyon (2004) declares that luxury is mostly a status symbol that stands for an indicator of what individuals can buy, according to Sombart (2013, p. 119), every kind of personal luxury is originated from an emotion arises from a pure desire.

With reference to psychologic and economic based luxury consumption approaches mentioned above; desires like gaining prestige, being different and being favored enable individuals to take pleasure in luxury products and direct them to consume. When the previous studies are examined in the literature, it was seen that the luxury value perceptions have an effect on consumers' buying tendencies, which are the last steps before purchasing behavior, like purchase intention and eagerness to buy intention (Hennigs et al., 2015; Cheah et al., 2015; Chen \& Kim, 2013; Li et al., 2013; Shukla \& Purani, 2012; Hung et al., 2011). Due to the fact that motivations that are defined as stimulated needs, lead consumer for a specific behavior (Mahato, 1989) it is thought that luxury value perceptions will have an important effect over shopping motivations. From this point of view following investigation model and hypotheses are developed: 


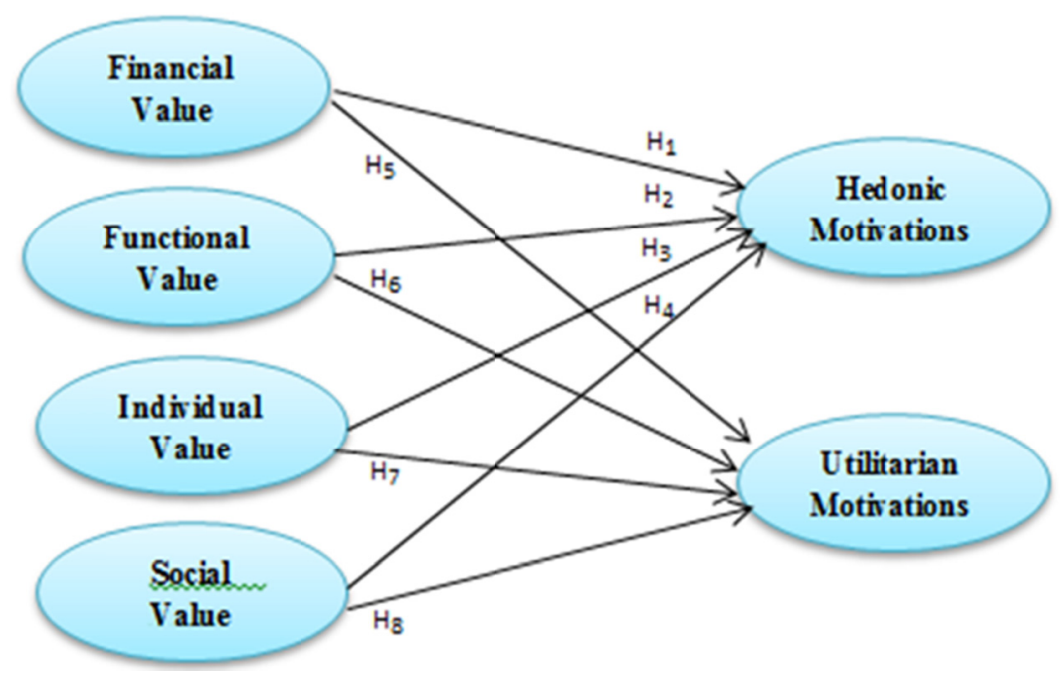

Figure 1. Research model

H1: Financial luxury value perception has an effect upon hedonistic motivations of individuals.

H2: Functional luxury value perception has an effect upon hedonistic motivations of individuals.

H3: Individual luxury value perception has an effect upon hedonistic motivations of individuals.

H4: Social luxury value perception has an effect on hedonistic motivations of individuals.

H5: Financial luxury value perception has an effect upon utilitarian motivations of individuals.

H6: Functional luxury value perception has an effect upon utilitarian motivations of individuals.

H7: Individual luxury value perception has an effect upon utilitarian motivations of individuals.

H8: Social luxury value perception has an effect upon utilitarian motivations of individuals.

\section{Methods}

\subsection{Research Design and Sample}

The study of population composed of individuals aged 18 and older that have purchase capacity in Turkey. In this study population is wanted to be represented by level of income and gender according to the context of the study. The population of Turkey is classified equally according to gender. The income group is divided into five categories as $20 \%$ sequences according to the level of household income by Turkey Statistics Corporation (TUIK). Aforementioned income groups are given in the Table 1.

Table 1. Disposable household income groups

\begin{tabular}{ll}
\cline { 2 - 2 } Disposable Household Income Groups & Income Ranges \\
\cline { 2 - 2 } Income Group 1: First 20\% & 2500TL and below \\
Income Group 2: Second 20\% & Between 2501TL and 3620TL \\
Income Group 3: Third 20\% & Between 3621TL and 5200TL \\
Income Group 4: Fourth 20\% & Between 5201TL and 10000TL \\
Income Group 5: Fifth 20\% & 10001TL and above \\
\hline
\end{tabular}

Source: TUIK (http://www.tuik.gov.tr/PreTablo.do?alt_id=1011).

Sample believed to be able to represent the population was chosen from the cities, which are determined according to nomenclature of territorial units for statistics of Turkey Statistics Corporation, relatively having high populations in 12 regions of Turkey (İstanbul, Ankara, İzmir, Kocaeli, Edirne, Adana, Kayseri, Samsun, Trabzon, Erzurum, Van, \& Diyarbakır). Gender and income group quotas were considered when selecting the sample.

P-value was taken as $0.50,99 \%$ confidence interval and $2.5 \%$ error margin was used in determining process of

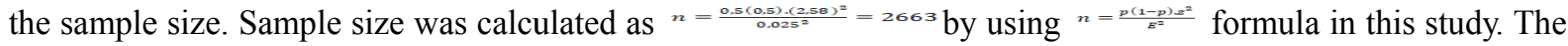


sample size for each city was determined according to ratio of that city's population within Turkey's population and quote was taken into consideration in terms of gender and income groups.

For the purpose of making necessary corrections on "questionnaire" form a pilot scheme was conducted to 50 people and in the light of it the questionnaire form was put into its final form. Data was gathered between $15^{\text {th }}$ of June- 15th of July 2016 from the individuals, who are fit in the quote and accepted to participate in the survey, answer the questionnaire.

2950 questionnaires were applied in total but 2857 of them were evaluated in consequence of elimination of the incomplete and inaccurate ones. A large part of the financial support necessary for data gathering was provided by Scientific Investigations Projects Committee of Sakarya University (SAÜ-BAPK, Project number: 2016-13-00-007).

\subsection{Measures}

Questionnaire form of the study is composed of 3 parts that contain demographic characteristics of participants, their statements related to their luxury value perception and consumption motivations. The "Luxury Value Perception" scale by Hennigs et al. (2012) which is composed of 21 statements, was used to measure luxury value perception of individuals. Aforesaid scale approaches luxury value perception in 4 main titles as financial, functional, personal and social by synthesizing all cognitive and emotional value factors. Five point Likert scale was used to determine individuals' agreement levels towards statements in the scale (1: strongly disagree...... 5: strongly agree).

"Hedonic Shopping Motivations" scale by Arnould \& Reynolds (2003) was used to reveal with which hedonic motivations do consumers carry out shopping act. Hedonic shopping motivations were surveyed with 6 sub-dimensions (Adventure, Value, Idea, Social, Gratification, and Role) and 19 statements in total. "Utilitarian Shopping Motivations" scale with 7 statements, used by Kim (2006) and accepted in the literature, was used to measure utilitarian shopping motivations. Five point Likert scale was used also when measuring consumption motivations (1: strongly disagree...... 5: strongly agree).

All of the scales that are used in the scope of the research were translated by means of specialists in their fields by using "back translation method" first from English to Turkish, afterwards from Turkish to English by another expert. Thus, the content integrity between the statements in the used scales and original scale was ensured.

\section{Results and Discussion}

Relationships between variables taking part in research model were examined by means of "structural equation modeling (SEM)" method in this study. However, construct validities and internal consistencies of relevant latent variables were tested by making a confirmatory factor analysis about luxury value perception, hedonic and utilitarian shopping motivations initially.

\subsection{The Test of the Dimensions of Luxury Value Perception}

It is seen that a statement that represents "financial value" (FIV4: 0.460) had a low standardized regression coefficient and did not explain its relative dimension sufficiently thus the analysis was repeated as a result of the first order confirmatory factor analysis applied to dimensions of luxury value perception. When fit indexes were investigated it was seen that the model does not adapt into the obtained data ( $\chi 2 / \mathrm{df}: 13.89$; GFI: 0.917; AGFI: 0.894; CFI: 0.906; TLI: 0.891; RMSEA: 0.067). When modification indexes of the model examined it was seen that a statement (IV3) taking part in the "individual value" dimension was excluded from the analysis because of having high covariance values among more than one variable. It was also seen that 2 variables (IV1-IV2) in this dimension have a relation with each other and a covariance value was attributed between the errors of them. It was seen that there is a high level of relationship between SV1-SV2 and SV3-SV4 variables that take part in "social value" dimension of luxury value perception and it was decided to define a covariance between these two couples of variables' errors. Standardized regression and error coefficients that belong to dimensions of luxury value perception are given under Table 2 after necessary modifications were applied. 
Table 2. Standardized regression and error coefficients of $1^{\circ}$ CFA Model belong to dimensions of luxury value perception

\begin{tabular}{|c|c|c|c|}
\hline Dimensions & Items & $\begin{array}{l}\text { Standardized regression } \\
\text { coefficient }(\lambda)\end{array}$ & $\begin{array}{l}\text { Error } \\
\text { coefficients (e) }\end{array}$ \\
\hline \multirow{3}{*}{$\begin{array}{l}\text { Financial } \\
\text { Value }\end{array}$} & FIV1.Luxury products are inevitably very expensive. & 0.596 & 0.645 \\
\hline & FIV2.Few people own a true luxury product. & 0.794 & 0.369 \\
\hline & FIV3.Truly luxury products cannot be mass-produced. & 0.480 & 0.769 \\
\hline \multirow{4}{*}{$\begin{array}{l}\text { Functional } \\
\text { Value }\end{array}$} & $\begin{array}{l}\text { FV1.The superior product quality is my major reason for buying } \\
\text { a luxury brand. }\end{array}$ & 0.660 & 0.565 \\
\hline & $\begin{array}{l}\text { FV2.I place emphasis on quality assurance over prestige when } \\
\text { considering the purchase of a luxury brand. }\end{array}$ & 0.658 & 0.567 \\
\hline & $\begin{array}{l}\text { FV3.I am inclined to evaluate the substantive attributes and } \\
\text { performance of a luxury brand rather than listening to the } \\
\text { opinions of others. }\end{array}$ & 0.607 & 0.631 \\
\hline & $\begin{array}{l}\text { FV4.A luxury brand that is preferred by many people but that } \\
\text { does not meet my quality standards will never enter into my } \\
\text { purchase consideration. }\end{array}$ & 0.542 & 0.706 \\
\hline \multirow{5}{*}{$\begin{array}{l}\text { Individual } \\
\text { Value }\end{array}$} & IV1.I derives self-satisfaction from buying luxury products. & 0.564 & 0.682 \\
\hline & IV2.Purchasing luxury products make me feel good. & 0.612 & 0.624 \\
\hline & $\begin{array}{l}\text { IV4. When I am in a bad mood, I may buy luxury brands as gifts } \\
\text { for myself to alleviate my emotional burden. }\end{array}$ & 0.708 & 0.499 \\
\hline & $\begin{array}{l}\text { IV5.I view luxury brand purchases as gifts for myself to } \\
\text { celebrate something that I do and feel excited about. }\end{array}$ & 0.791 & 0.374 \\
\hline & $\begin{array}{l}\text { IV6.I view luxury brand purchases gifts for myself to celebrate } \\
\text { an occasion that I believe is significant to me. }\end{array}$ & 0.774 & 0.401 \\
\hline \multirow{7}{*}{ Social Value } & $\begin{array}{l}\text { SV1.I like to know what luxury brands and products make good } \\
\text { impressions on others. }\end{array}$ & 0.671 & 0.550 \\
\hline & $\begin{array}{l}\text { SV2.To me, my friends' perceptions of different luxury brands } \\
\text { or products are important. }\end{array}$ & 0.694 & 0.518 \\
\hline & $\begin{array}{l}\text { SV3.I pay attention to what types of people buy certain luxury } \\
\text { brands or products. }\end{array}$ & 0.706 & 0.501 \\
\hline & $\begin{array}{l}\text { SV4.It is important to know what others think of people who } \\
\text { use certain luxury brands or products. }\end{array}$ & 0.717 & 0.485 \\
\hline & $\begin{array}{l}\text { SV5.I am interested in determining what luxury brands I should } \\
\text { buy to make good impressions on others. }\end{array}$ & 0.763 & 0.418 \\
\hline & $\begin{array}{l}\text { SV6.It is important that others have a high opinion of how I } \\
\text { dress and look. }\end{array}$ & 0.684 & 0.532 \\
\hline & $\begin{array}{l}\text { SV7.If I were to buy something expensive, I would worry about } \\
\text { what others would think of me. }\end{array}$ & 0.688 & 0.527 \\
\hline
\end{tabular}

It was seen that fit indexes of models are satisfying enough after modifications ( $\chi 2$ /df: 7.058; GFI: 0.962; AGFI: 0.950; CFI: 0.958; TLI: 0.949; RMSEA: 0.046). Because of the fact that the $\chi^{2}$ value is sensitive to the sample size, the $\chi^{2}$ df value may not give the desired results in terms of suitability of the model. Hereby, decisions are made according to the other fit indexes (Byrne, 2010). It is possible to say that statements under the scales represent the dimensions well because of the standardized regression coefficients and fit statistics of statements, which belong to dimensions of luxury value perception, are satisfying.

Two basic approaches as convergent and discriminant validity are used for measuring the construct validity. Discriminant validity is applied to test whether luxury value dimensions are different structures or not. Therefore, first by fixing correlations between dimensions in the model at 1 a "restricted model" was tested, then an "unrestricted" model in which the correlations between dimensions are set free was also tested, and then these two models were compared (Bagozzi et al., 1991). The differences between Chi Square and degrees of freedom (df) for restricted and unrestricted models belonging to dimensions of luxury value perception is seen under Table 3 . 
Table 3. Evaluation of discriminant validity of luxury value perceptions dimensions

\begin{tabular}{lll}
\hline & $\chi^{2}$ & df \\
\hline Model of correlations fixed at 1 & 3223.700 & 149 \\
Model of correlations free & 1009.254 & 143 \\
$\Delta \chi^{2}$ & 2214.446 & \\
$\Delta$ df & & 6 \\
\hline
\end{tabular}

$\chi^{2}$ value is 12.59 at 6 degrees of freedom and 0.05 significance level and when conclusions are drawn. It can be said that discriminant validity is provided because $\Delta \chi^{2}$ value is larger than $\chi^{2}$ value $(2214.446>12.59)$.

The relationship between every statement and the structure that the statement bound up with is investigated by means of convergent validity that is another approach which is used to measure structural validity. For convergent validity, Average Variance Extracted (A.V.E) value must be higher than 0.5 and Composite Reliability (C.R.) ratio must be greater than A.V.E. (Hair et al., 2010). C.R. and A.V.E values for every dimension for luxury value perception and the fact that C.R values for every dimension are larger than A.V.E values are seen under Table 4. On the other hand, it is seen that A.V.E values in every dimension except social value are smaller than 0.5. Owing to the statement of Fornell \& Larcker (1981) that says A.V.E values can be accepted as lower than 0.5 in the circumstances that the other reliability criteria are provided, it can be said that convergent validity is ensured for all the other dimensions.

Table 4. Analysis results for reliability and convergent validity of dimensions of luxury value perception

\begin{tabular}{cllll} 
& & Cronbach Alpha & C.R.* & A.V.E.** \\
\cline { 2 - 5 } & Financial Value & 0.64 & 0.66 & 0.41 \\
& Functional Value & 0.71 & 0.71 & 0.38 \\
& Individual Value & 0.83 & 0.82 & 0.49 \\
& Social Value & 0.88 & 0.87 & 0.50 \\
\cline { 2 - 5 } Note. $*$ Composite Reliability & $($ C.R. $):\left(\sum \lambda\right)^{2} /\left(\sum \lambda\right)^{2}+\sum e .{ }^{* *}$ Average Variance Extracted $($ A.V.E. $): \sum \lambda^{2} / \sum \lambda^{2}+\sum e$ and $e=1-\lambda^{2}$.
\end{tabular}

Cronbach Alpha, C.R. and A.V.E. values are applied to specify reliability of every dimension that constitutes luxury value perception. It is expected Cronbach Alpha values to be greater than the critical value 0.70 (Hair et al., 2010), C.R values to be greater than 0.70 and A.V.E values to be greater than 0.50 (Fornell \& Larcker, 1981). It is seen that Cronbach Alpha and C.R values are larger than the critical value 0.70 for the entire dimensions except financial value when findings in Table 4 are evaluated. The reason for Cronbach Alpha and C.R values to be under 0.70 for financial value may be arise from being measured with only three observable variables. Nunnally states that this value can be accepted even between 0.50 and 0.60 for some certain number of occasions (Nunnally, 1978). The aforementioned statement is also valid for A.V.E values. Thus, it can be said that internal consistency of every dimensions is satisfactory enough.

\subsection{The Test of the Dimensions of Hedonic Shopping Motivations}

As a result of the first order confirmatory factor analysis applied to hedonic shopping motivations, it is seen that standardized regression coefficient of statements belonging to variables are not low, but when fit indexes were examined it is observed that $\chi 2 / \mathrm{df}$ and TLI values do not show sufficient adaptation ( $\chi 2 / \mathrm{df}: 14.05$; GFI: 0.931; AGFI: 0.905; CFI: 0.914; TLI: 0.892; RMSEA: 0.068). When modification indexes of the model were evaluated it was seen that a statement (HA4) from the "adventure" dimension was excluded from the analysis because of having high covariance values among more than one variable. It was seen that there is a high level of relationship between HV3-HV4 variables in "value" dimension and it was decided that a covariance value had to be attributed between the errors of them. Standardized regression, error coefficients and fit indexes of hedonic shopping motivations are given under Table 5 after necessary modifications were applied. 
Table 5. Standardized regression and error coefficients of $1^{\circ}$ CFA model relating to dimensions of hedonic shopping motivations

\begin{tabular}{|c|c|c|c|}
\hline Dimensions & Items & $\begin{array}{l}\text { Standardized regression } \\
\text { coefficient }(\lambda)\end{array}$ & $\begin{array}{l}\text { Error } \\
\text { coefficients (e) }\end{array}$ \\
\hline \multirow{3}{*}{ Adventure } & HA1.To me, shopping is an adventure & 0.725 & 0.474 \\
\hline & HA2.I find shopping stimulating. & 0.743 & 0.448 \\
\hline & HA3.Shopping makes me feel like I am in my own universe & 0.739 & 0.454 \\
\hline \multirow{4}{*}{ Value } & HV1.For the most part, I go shopping where the sales are. & 0.688 & 0.526 \\
\hline & HV2.I enjoy looking for discounts when I shop. & 0.731 & 0.466 \\
\hline & HV3.I try to get the cheapest product when I shop. & 0.459 & 0.789 \\
\hline & HV4.I do shopping to take advantage of discount times. & 0.495 & 0.755 \\
\hline \multirow{3}{*}{ Idea } & HI1.I go shopping to keep up with the new fashions. & 0.635 & 0.597 \\
\hline & HI2.I go shopping to see what new products are available. & 0.761 & 0.421 \\
\hline & HI3.I go shopping to keep up with the trends & 0.829 & 0.313 \\
\hline \multirow{3}{*}{ Social } & HS1.Shopping is a good opportunity to socialize. & 0.731 & 0.466 \\
\hline & $\begin{array}{l}\text { HS2.Shopping with my friends and family is a bonding } \\
\text { experience. }\end{array}$ & 0.644 & 0.586 \\
\hline & HS3.I enjoy socializing with others when I shop. & 0.665 & 0.558 \\
\hline \multirow[t]{2}{*}{ Gratification } & $\begin{array}{l}\text { HG1. When I'm in a down mood, I go shopping to make me } \\
\text { feel better. }\end{array}$ & 0.743 & 0.449 \\
\hline & HG2.To me, shopping is a way to relieve stress. & 0.779 & 0.393 \\
\hline \multirow{3}{*}{ Role } & $\begin{array}{l}\text { HR1.I like shopping for others because when they feel good I } \\
\text { feel good }\end{array}$ & 0.606 & 0.633 \\
\hline & HR2.I enjoy shopping for my friends and family. & 0.654 & 0.572 \\
\hline & $\begin{array}{l}\text { HR3.I enjoy shopping around to find the perfect gift for } \\
\text { someone. }\end{array}$ & 0.607 & 0.631 \\
\hline$\chi 2 /$ df: 9.642 & $\begin{array}{llll}0.954 & \text { AGFI: } 0.934 & \text { CFI: } 0.945 & \text { TLI: } 0.930\end{array}$ & RMSEA:0.055 & \\
\hline
\end{tabular}

It was seen with the assessment of Table 5 that the model developed a good fit index and information for discriminant validity of hedonic shopping motivations dimensions is given under Table 6 .

Table 6. Evaluation of discriminant validity of dimensions of hedonic shopping motivations

\begin{tabular}{lll}
\hline & $\chi^{2}$ & df \\
\hline Model of correlations fixed at 1 & 2809.838 & 134 \\
Model of correlations free & 1147.389 & 119 \\
$\Delta \chi^{2}$ & 1662.44 & \\
$\Delta$ df & & 15 \\
\hline
\end{tabular}

In the light of the $\chi 215 ; 0.05=25$ and $\Delta \chi 2=1662.44>25.00$ results, it can be said that the discriminant validity was provided.

C.R., A.V.E. and Cronbach alpha values for convergent validity and reliability of hedonic motivation dimensions appear in Table 7. It was seen that Cronbach alpha value of every dimension except "role" is higher than critical value 0.70 , and as to "role" dimension it is acceptable. C.R. values of dimensions are higher than A.V.E. values. Even though A.V.E values for value, social and role dimensions are lower than 0.50 , they are acceptable as it was declared before (Fornell \& Larcker, 1981).

Table 7. Convergent validity and reliability analysis results of dimensions of hedonic shopping motivations

\begin{tabular}{llll}
\hline & Cronbach Alpha & C.R. & A.V.E. \\
\hline Adventure & 0.78 & 0.78 & 0.54 \\
Value & 0.71 & 0.69 & 0.37 \\
Idea & 0.78 & 0.79 & 0.56 \\
Social & 0.72 & 0.72 & 0.46 \\
Gratification & 0.73 & 0.73 & 0.58 \\
Role & 0.66 & 0.66 & 0.39 \\
\hline
\end{tabular}


The second order confirmatory factor analysis was applied to data in order to identify every sub dimension of statements that represent hedonic motivations and how well these sub dimensions represent hedonic motivations. The related dimensions of the statements in the sub dimensions and all of these dimensions except "value" explain "hedonic motivations" with high structural coefficients (Adventure: 0.984; Gratification: 0.912; Social: 0.893; Idea: 0.792; Role: 0.767; Value: 0.320). It was seen that fit indexes of hedonic motivation model, that is represented with 6 dimensions and 18 statement in total, is satisfactory $(\chi 2 / \mathrm{df}: 10.749$; GFI: 0.945; AGFI: 0.927; CFI: 0.934; TLI: 0.921; RMSEA: 0.058).

\subsection{The Test of Utilitarian Shopping Motivations}

As a result of first order confirmatory factor analysis applied to hedonic shopping motivations, because of the low standardized regression coefficient of two statements (UM1:0.276; UM6:0.212) the analysis were repeated by removing these statements but still it was seen that the model was not sufficiently adapted $(\chi 2 / \mathrm{df}: 22.00$; GFI: 0.970; AGFI: 0.940; CFI: 0.924; TLI: 0.885; RMSEA: 0.086). It is seen that there is high correlation between UM2-UM3 coded variables when modification indexes of model were evaluated, therefore covariance was attributed between the errors of them. Standardized regression, error coefficients and model's fit indexes of utilitarian motivations were given under Table 8 after modifications were applied.

Table 8. Standardized regression and error coefficients of $1^{\circ} \mathrm{CFA}$ model of utilitarian motivations

\begin{tabular}{|c|c|c|c|}
\hline Variable & Items & $\begin{array}{l}\text { Standardized } \\
\text { regression } \\
\text { coefficient }(\lambda)\end{array}$ & $\begin{array}{l}\text { Error } \\
\text { coefficients (e) }\end{array}$ \\
\hline \multirow{5}{*}{$\begin{array}{l}\text { Utilitarian } \\
\text { Motivations }\end{array}$} & $\begin{array}{l}\text { UM2.It is important to accomplish what I had planned on a particular } \\
\text { shopping trip. }\end{array}$ & 0.562 & 0.684 \\
\hline & $\begin{array}{l}\text { UM3. On a particular shopping trip, it is important to find items I am } \\
\text { looking for. }\end{array}$ & 0.659 & 0.565 \\
\hline & UM4.It feels good to know that my shopping trip was successful. & 0.763 & 0.417 \\
\hline & UM5.I like to feel smart about my shopping trip & 0.690 & 0.524 \\
\hline & $\begin{array}{l}\text { UM7.It is important that I buy the product I really need my shopping } \\
\text { trip. }\end{array}$ & 0.405 & 0.836 \\
\hline$\chi 2 / \mathrm{df}: 11.39$ & $\begin{array}{lllll}\text { GFI: } 0.994 & \text { AGFI: } 0.977 & \text { CFI: } 0.988 & \text { TLI: } 0.969 & \text { RM }\end{array}$ & \multirow[t]{2}{*}{ RMSEA:0.060 } & \\
\hline \multicolumn{3}{|c|}{ Cronbach Alpha: $0.76 \quad$ C.R.: $0.76 \quad$ A.V.E.: 0.40} & \\
\hline
\end{tabular}

It was seen that Cronbach alpha and C.R. values of utilitarian motivations are higher than critical value level and A.V.E. value is below 0.5 but it is at an acceptable level. Thus, it can be said that reliability and structure validity is valid for utilitarian motivations.

\subsection{Measurement Model Test}

Fix indexes of the model were examined before hypotheses test of research model. It was seen that measure model build good fit indexes as a result of evaluations ( $\chi 2 / \mathrm{df:}$ 6.452; GFI: 0.915; AGFI: 0.904; CFI: 0.910; TLI: 0.902; RMSEA: 0.044). Thus, validity and reliability analysis of measure model were introduced.

Table 9. The evaluation of discriminant validity for measurement model

\begin{tabular}{lll}
\hline & $\chi^{2}$ & df \\
\hline Model of correlations fixed at 1 & 8727.242 & 806 \\
Model of correlations free & 5110.173 & 792 \\
$\Delta \chi^{2}$ & 3617.069 & \\
$\Delta$ df & & 14 \\
\hline
\end{tabular}

In the light of the $\Delta \chi^{2}=3617.069>\chi_{14 ; 0,05}^{2}=23.68$ results, it can be said that the discriminant validity was provided when Table 9 is evaluated. Cronbach alpha, C.R. and A.V.E values for convergent validity and reliability of measurement model were given under Table 10. 
Table 10. Analysis results of convergent validity and reliability of measurement model

\begin{tabular}{llll}
\hline & Cronbach Alpha & C.R. & A.V.E. \\
\hline Financial Value & 0.64 & 0.83 & 0.62 \\
Functional Value & 0.71 & 0.84 & 0.57 \\
Individual Value & 0.83 & 0.92 & 0.70 \\
Social Value & 0.88 & 0.94 & 0.68 \\
Hedonic Motivations & 0.89 & 0.94 & 0.74 \\
Utilitarian Motivations & 0.76 & 0.88 & 0.61 \\
\hline
\end{tabular}

It was seen that convergent validity was provided for all dimensions due to C.R values' of all the variables in measurement model being greater than their A.V.E values and A.V.E. values' being higher than critical value level 0.50. Similarly, when all findings are evaluated it was seen that Cronbach alpha and C.R values of all dimensions, except "financial" value dimension, are higher than critical value level 0.70 . It was seen that Cronbach alpha value has produced a value under 0.70 because financial value was measured within three statements. It is known that values that are a little lower than critical value is also accepted in similar situations. Therefore, it can be said that reliability was provided for all dimensions in measurement model.

\subsection{Structural Model and Hypotheses Testing}

Structural model test results showed that there exists a relationship between "social value" and "individual value" dimensions of luxury value perceptions. Thus, covariance was attributed between these two latent variables. It can be said as a justification of this it is related to leaving a good impression on others when social value dimension of luxury is generally thought. And this situation is an output of individual's social needs. Individual value can be thought as rewarding of self-value that one attributes to himself. The desire of acquiring a luxury product can be thought as a part of interactive psychological process on behalf of rewarding an individual in an overlapping way of his own identity and giving social messages while using this product. Therefore, it is not surprising that social and individual dimensions have high correlations. Another modification advice is the covariance that has to be attributed between "functional" and "financial" value variables. It is hoped that characteristics of luxury that refer to the functional sides of luxury has an effect on financial value of a luxury and it is expected by consumers that functional characteristics of luxury products with high financial value to be satisfactory. No harm is seen to make this definition from this point of view.

It was seen that fit index of model brought good results after modifications were done ( $\chi 2$ /df: 6.748; GFI: 0.914; AGFI: 0.902; CFI: 0.904; TLI: 0.900; RMSEA: 0.045).

Table 11. Standardized regression coefficient and the results of hypotheses testing

\begin{tabular}{|c|c|c|c|c|}
\hline & $\begin{array}{l}\text { Standardized regression } \\
\text { coefficient }\end{array}$ & C.R.* & $\begin{array}{l}\text { Sig. } \\
\text { (P) }\end{array}$ & Result \\
\hline Financial V. $\longrightarrow$ Hedonic M. & 0.084 & 4.210 & $* * *$ & $\mathrm{H}_{1}$ Accepted \\
\hline Functional V. $\longrightarrow$ Hedonic M. & 0.065 & 3.385 & $* * *$ & $\mathrm{H}_{2}$ Accepted \\
\hline Individual V. $\longrightarrow$ Hedonic $\mathrm{M}$. & 0.612 & 14.810 & $* * *$ & $\mathrm{H}_{3}$ Accepted \\
\hline Social V. $\longrightarrow$ Hedonic M. & 0.219 & 6.139 & $* * *$ & $\mathrm{H}_{4}$ Accepted \\
\hline Financial V. $\longrightarrow$ Utilitarian M. & 0.201 & 7.217 & $* * *$ & $\mathrm{H}_{5}$ Accepted \\
\hline Functional $\mathrm{V} \longrightarrow$ Utilitarian $\mathrm{M}$. & 0.522 & 15.768 & $* * *$ & $\mathrm{H}_{6}$ Accepted \\
\hline Individual V $\longrightarrow$ Utilitarian $\mathrm{M}$. & 0.137 & 3.004 & 0.003 & $\mathrm{H}_{7}$ Accepted \\
\hline 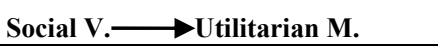 & -0.136 & -3.000 & 0.003 & $\mathrm{H}_{8}$ Accepted \\
\hline
\end{tabular}

Note. *C.R.: Critical Ratio.

When findings of structural equation model in Table 11 were evaluated it was seen that individual value dimension (0.612) of luxury has the highest relative effect over hedonic motivations, and social value (0.219), financial value $(0.084)$ and functional value $(0.065)$ follow it respectively. The dimension of luxury value perception that has the highest relative effect over utilitarian motivations is "functional" dimension (0.522). Financial value (0.201), individual value (0.137) and social value (-0.136) follow it respectively. When each of the luxury value perception dimensions' impact over the hedonic motivations was investigated it was seen that this impact was positive and significant and therefore H1, H2, H3 and H4 hypotheses were supported. Financial, functional and individual dimensions of luxury value perception have a positive effect over utilitarian motivations, while this effect is negative for social value dimension. From this point of view H4, H5, H6 and H7 
hypotheses were supported. Graphical design of hypotheses test results appears in Figure 2.

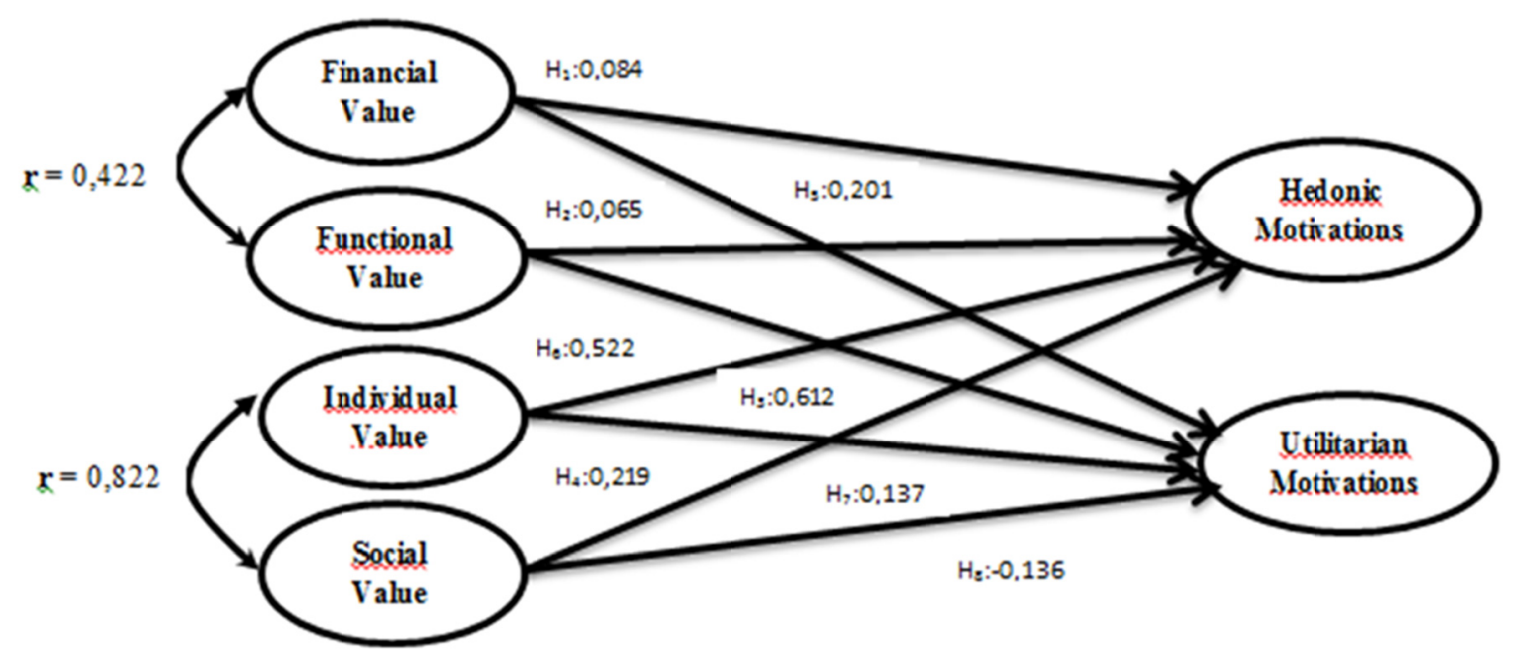

Figure 2. Hypotheses testing result

\section{Conclusion and Implications}

It was aimed to expose whether consumers' luxury value perceptions have an affect or not on their shopping motivations with this study. It is identified that luxury value perception is explained with financial, functional, individual and social value dimensions; shopping motivations split into two basic dimensions as hedonic and utilitarian. Also, it was seen that hedonic motivation is composed of sub dimensions as adventure, value, idea, social, gratification and role. As a result of the first and second order confirmatory factor analysis applied to data, findings were reached that are such as to support studies in the literature.

When the findings acquired as a consequence of structural equation modeling were evaluated $\mathrm{H} 1, \mathrm{H} 2, \mathrm{H} 3$ and H4 hypotheses were supported due to financial, functional, individual and social dimensions of luxury value perception's being effective in a significant and positive way statically upon hedonic shopping motivations. The idea that "luxury motivates individuals" desires and emotions relevant to human soul of Sombart (2013) is supported with these results. In this way, it can be said that consumers' perceptions related to luxury product, brand or services affect hedonic shopping motivations that are based on their fun, pleasure and fantasy feelings hence this leads them to luxury consumption.

It was seen that especially individual and social dimensions of luxury have a significant explanatoriness upon hedonic shopping motivations. When explaining the effect of individual value dimension, the idea that individuals turn onto luxury with the aim of emphasizing their identity and self-expression when meeting the need of "self-actualization" from Maslow's "theory of hierarchy of needs" dominates. According to the studies in the literature it was seen that individuals ascribe symbolic meanings to their identities with their possessions (Vigneron \& Johnson, 2004; Solomon, 2007) or they head towards to luxury products for feeding or developing this identity (Douglas \& Isherwood, 1979; Hirschman \& Holbrook, 1982; Belk, 1988; Dittmar, 1994). According to the study handled by Birdwell'in (1968), individuals' ego images are more powerful when they possess luxurious cars compared to possessing economy class ones. Hereby, the reasons why individual value dimension of luxury has the most affect over hedonic shopping motivations are individuals' luxury product perceptions, their perceiving themselves emotionally more successful and powerful by consuming these products, luxury products' enabling them to shape their identity and empowering their status socially or providing their status.

Social value of luxury's being the second dimension that has relative importance over hedonic shopping motivations can be explained by Veblen's (1899) "conspicuous consumption theory". According to the theory, individuals send signals to others in the society about their relativistic status while consuming luxury goods or services they achieve conspicuously in order to display their income or wealth. According to Eastman et al. (1999); individuals are in a struggle for buying an expensive product to add prestige to their status in society and to satisfy their ego. And also when meeting the needs taking place in Maslow's "hierarchy of needs" "social" and "esteem" and the needs "power" and "affiliation" in Mc. Clelland's "Theory of needs", consumption towards luxury goods comes into prominence. 
Another reason why luxury individual and social value perception have significant effect over hedonic shopping motivations is believed to be related to the location where luxury market is located in Turkey. Luxury goods that had been accessible by only elite minority until the 19th century, could be reached by the consumer groups named as upper-middle and middle class with "democratization process" of luxury. This situation made a significant contribution to the development of luxury market in the world, consequently in Turkey, too. Therefore, luxury market investigations have increased. According to one of these studies, the report of Deloitte in 2015, progression of luxury market is composed of 5 stages and as in many other developed countries the luxury market in Turkey is also at its $3^{\text {rd }}$ stage; "show off". At this stage the fact, that middle income group enlarges the luxury market and luxury products' being seen as status symbol is one of the reasons for consumers to tend to luxury stands out. Studies handled by Sututemiz \& Kurnaz (2016) and Kurnaz (2016) are such as to support the position of luxury market in Turkey. Thus, it was revealed with this study that privileged positions provided by luxury like social status and prestige direct consumers to consume with hedonic purposeful motivations.

Another important result of this study is H5, H6, H7 and H8 hypotheses' being approved. According to this, when the financial, functional and individual value dimensions of luxury have positive effects on utilitarian shopping motivations, social dimension's effect is negative. In other words, the more willing consumers have to meet their status, prestige and show-off needs with luxury, the worse this situation effects their utilitarian luxury consumption motivation negatively. This may be caused by Turkey's being at the "show-off" stage in the luxury market. In other words, while show-off purpose of luxury perception increases, gaining benefit purpose luxury consumption motivation decreases and this also shows that the social value of luxury triggers the hedonic motivations. Functional and financial values have relatively more importance upon utilitarian motivations when the degrees of influence were investigated. Studies show that luxury products play an important role to provide practicality, desired performance and high quality (Tellis \& Gaeth, 1990; Sheth \& diğ., 1991; Smith \& Colgate, 2007) and this situation has an impact over utilitarian motivations of individuals.

It is thought that an understanding towards consumers was developed with this study by detecting which consumption motivations of individuals are affected by luxury perceived value. Hereby, the results of the study provide important clues for marketers to make contact with consumers more effectively, to examine the consumption phenomenon and to develop marketing industry.

\section{Recommendations for Future Study and Limitations}

Because the investigation data were gathered in a given time, with restricted source in a lump, participants filled in questionnaire instantly and this situation created an ignorance of perception alteration that may cause a constraint based on time period. Another constraint of the study is that quota sampling was applied in sample selection. In this study sample was chosen according to gender and household disposable income level to represent population. Variables like age, marital status should be taken into consideration for a more representative sample.

It was seen that every dimension of luxury value perception has an effect over shopping motivations along with becoming different in their relative effects. Similarities or differences can be revealed by addressing different countries and cultures for further studies. Approaching hedonic and utilitarian shopping motivations in a multiple manner can bring and develop a deeper understanding about relationships between variables. Another suggestion can be brought towards revealing how dimensions of luxury value perception affect consumers' shopping behaviors.

\section{References}

Aaker, J. L., \& Lee, A. Y. (2006). Understanding Regulatory Fit. Journal of Marketing Research, XLIII, February, 15-19. https://doi.org/10.1509/jmkr.43.1.15

Antonides, G., \& Van Raaij, W. F. (1998). Consumer Behavior, a European Perspective. Chichester: John Wiley and Sons.

Apospori, E., Papalexandris, N., \& Galanaki, E. (2005). Entreprenurial and Professional CEO's, Differences in Motive and Responsibility Profile. Leadership and Organization Development Journal, 26(2), 141-162. https://doi.org/10.1108/01437730510582572

Arnold, M. J., \& Reynolds, K. E. (2003). Hedonic Shopping Motivations. Journal of Retailing, 79(1), 77-95. https://doi.org/10.1016/S0022-4359(03)00007-1

Babin, B. J., \& Attaway, J. S. (2000). Atmospheric Affect as a Tool for Creating Value and Gaining Share of Customer. Journal Business Research, 49(2), 91-99. https://doi.org/10.1016/S0148-2963(99)00011-9 
Babin, B. J., \& Babin, L. (2001). Seeing Something Different? A model of Schema Typicality, Consumer Affect, Purchase Intentions and Perceived Shopping Value. Journal Business Research, 54, 89-96. https://doi.org/10.1016/S0148-2963(99)00095-8

Babin, B. J., Darden, W. R., \& Griffin, M. (1994). Work and/or Fun: Measuring Hedonic and Utilitarian Shopping Value. The Journal of Consumer Research, 20(4), 644-656. https://doi.org/10.1086/209376

Bagozzi, R. P., Youjae, Y., \& Lynn, W. P. (1991). Assessing Construct Validity in Organizational Research. Administrative Science Quarterly, 36(3), 421-458. https://doi.org/10.2307/2393203

Bagwell, L. S., \& Bernheim, B. D. (1996). Veblen Effects in a Theory of Conspicuous Consumption. American Economic Review, 86(3). 349-373.

Batra, R., \& Ahtola, O. T. (1991). Measuring the Hedonic and Utilitarian Sources of Consumer Attitudes. Marketing Letters, 2, 159-170. https://doi.org/10.1007/BF00436035

Baudrillard, J. (2004) Tüketim Toplumu. In H. Deliçaylı \& F. Keskin (Çev. Ed.). İstanbul: Ayrıntı Yay.

Belk, R. W. (1988). Possessions and The Extended Self. Journal of Consumer Research, 2(2), 139-168. https://doi.org/10.1086/209154

Berry, C. J. (1994). The Idea of Luxury. A Conceptual and Historical Investigation. Cambridge: Cambridge University Press. https://doi.org/10.1017/CBO9780511558368

Berthon, P., Pitt, L., Parent, M., \& Berthon, J. P. (2009). Aesthetics and Ephemerality: Observing and Preserving The Luxury Brand. California Management Review, 52(1), 45-66. https://doi.org/10.1525/cmr.2009.52.1.45

Bian, Q., \& Forsythe, S. (2012). Purchase Intention For Luxury Brands: A Cross Cultural Comparison. Journal of Business Research, 65(10), 1443-1451. https://doi.org/10.1016/j.jbusres.2011.10.010

Birdwell, A. E. (1968). A Study of the Influence of Image Congruence on Consumer Choise. The Journal of Business, 41(1), 76-88. https://doi.org/10.1086/295047

Bocock, R. (2005). Tüketim. 2. Baskı. Ankara: Dost Kitabevi Yayınları.

Brun, A., \& Castelli, C. (2013). The Nature of Luxury: A Consumer Perspective. International Journal of Retail \& Distribution Management, 41(11/12), 823-847. https://doi.org/10.1108/IJRDM-01-2013-0006

Byrne, B. M. (2010). Structural Equation Modeling with AMOS. New York: Taylor and Francis Group.

Carlson, K.B. (2009). Brown Bag Couture: The Recession Is Forcing Shopaholics To Get Sneaky With Their Purchases. Retrieved from http://www.nationalpost.com/news/story.html?id=14859822009

Cheah, I., Phau, I., Chong, C., \& Shimul, A. S. (2015). Antecedents and Outcomes of Brand Prominence on Willingness To Buy Luxury Brands. Journal of Fashion Marketing and Management, 19(4), 402-415. https://doi.org/10.1108/IJRDM-01-2013-0006

Chen, J., \& Kim, S. (2013). A Comparison Of Chinese Consumers' Intentions To Purchase Luxury Fashion Brands For Self-Use And For Gifts. Journal Of International Consumer Marketing, 25, 29-44. https://doi.org/10.1080/08961530.2013.751796

Cornell, A. (2002). Cult of Luxury: The New Opiate of The Masses. Australian Financial Review, 47.

Crowley, A. E., Spangenberg, E. R., \& Hughes, K. R. (1992). Measuring the Hedonic and Utilitarian Dimensions of Attitudes Toward Product Categories. Marketing Letters, 3(3), 239-249. https://doi.org/10.1007/BF00994132

Dittmar, H. (1994). Material Possessions as Stereotypes: Material Images of Different Socio-Economic Groups. Journal of Economic Psychology, 15(4), 561-585. https://doi.org/10.1016/0167-4870(94)90011-6

Douglas, M., \& Isherwood, B. (1979). The World of Goods Basic. New York: Basic Books.

Dubois, B., \& Duquesne, P. (1993). The Market For Luxury Goods: Income Versus Culture. European Journal of Marketing, 27(1), 35-44. https://doi.org/10.1108/03090569310024530

Eastman, J. K., Goldsmith, R. E., \& Flynn, L. R. (1999). Status Consumption in Consumer Behavior: Scale Development and Validation. Journal of Marketing Theory and Practice, 7, 41-52. https://doi.org/10.1108/03090569310024530

Fischer, E., \& Arnold, S. J. (1990). More than a Labor of Love: Gender Rolesand Christmas Shopping. Journal of Consumer Research, 17, 333-345. https://doi.org/10.1086/208561 
Fornell, C., \& Larcker, D. (1981). Evaluating Structural Equation Models With Unobservable Variables and Measurement Error. Journal of Marketing Research, 18(1), 39-50. https://doi.org/10.1086/208561

Grossman, G. M., \& Shapiro, C. (1988). Foreign counterfeiting of Status Goods. Quarterly Journal of Economics, 103(1), 79-100. https://doi.org/10.2307/1882643

Guyon, J. (2004). The Magic Touch. Fortune, 150(4), 34-39.

Hair, J. F., Black, W. C., Babin, B. J., \& Anderson, R. E. (2010). Multivariate Data Analysis. (7th ed.). New Jersey: Prentice Hall.

Hauck, E., \& Stanforth, N. (2007). Cohort Perception of Luxury Goods and Services. Journal of Fashion Marketing and Management, 11(2), 175-188. https://doi.org/10.1108/13612020710751365

Hennigs, N., Wiedmann, K. P., Klarmann, C., \& Behrens, S. (2015). The Complexity of Value in The Luxury Industry: From Consumers' Individual Value Perception To Luxury Consumption. International Journal of Retail \& Distribution Management, 43(10/11), 922-939. https://doi.org/10.1108/IJRDM-07-2014-0087

Hennigs, N., Wiedmann, K. P., Klarmann, C., Strehlau, S., Godey, B., Pederzoli, D., ... Oh, H. (2012). What Is the Value of Luxury? A Cross-Cultural Consumer Perspective. Psychology and Marketing, 29(12), 1018-1034. https://doi.org/10.1002/mar.20583

Hirschman, E. C., \& Holbrook, M. B. (1982). Hedonic Consumption: Emerging Concepts, Methods and Propositions. Journal of Marketing, 46, 92-101. https://doi.org/10.2307/1251707

Hung, K., Chen, A. H., Peng, N., Hackley, C., Chou, C., Hackley, C., \& Tiwsakul, A. R. (2011). Antecedents of Luxury Brand Purchase Intention. Journal of Product and Brand Management, 20(6), 456-467. https://doi.org/10.1108/10610421111166603

Jones, M., Reynolds, K., \& Arnold, M. (2006). Hedonic and Utilitarian Shopping Value, Investigating Differential Effects on Retail Outcomes. Journal Business Research, 59(9), 974-981. https://doi.org/10.1016/j.jbusres.2006.03.006

Kapferer, J. N. (1998). Why Are We Seduced By Luxury Brands? Journal of Brand Management, 6(1), 44-49. https://doi.org/10.1057/bm.1998.43

Kim, H. S. (2006). Using Hedonic and Utilitarian Shopping Motivations to Profile Inner City Consumers. Journal of Shopping Center Research, 13(1), 57-79.

Koç, E. (2012). Tüketici Davranışı ve Pazarlama Stratejileri, Global ve Yerel Yaklaşım. Seçkin Yayıncılık, Ankara.

Kurnaz, A. (2016). The Influence of Luxury Value Perception Towards Purchase Tendency: Sample of Turkey. $\mathrm{PhD}$. Thesis. Institute of Social Sciences. Sakarya University. Sakarya.

Leahy, J., \& P. Betts. (2010). Is the Tide Starting to turn for the Luxury Industry? 2016. Retrieved from http://www.ft.com/cms/s/0/fa95cc08-062c-11df-8c97-00144feabdc0.html.2010

Li, G., Li, G., \& Kambele, Z. (2012). Luxury Fashion Brand Consumers in China: Perceived Value, Fashion Lifestyle, and Willingness To Pay. Journal of Business Research, 65(10), 1516-1522. https://doi.org/10.1016/j.jbusres.2011.10.019

Li, N., Robson, A., \& Coates, N. (2013). Chinese Consumers' Purchasing: Impact of Value and Affect. Journal of Fashion Marketing and Management, 17(4), 486-508. https://doi.org/10.1108/JFMM-03-2013-0030

Lynn, M., \& Harris, J. (1997). The Desire For Unique Consumer Products: A New Individual Differences Scale. Psychology and Marketing, 601-616. https://doi.org/10.1002/(SICI)1520-6793(199709)14:6<601::AID-MAR5>3.0.CO;2-B

Mahato, W. H. (1989). Motives Must be Differential from Needs, Drives, Wants: Strategy Implications. European Journal Of Marketing, 23(3). https://doi.org/10.1108/EUM0000000000558

Maslow, A. H. (1970). Motivation and Personality. Harper and Row Publishers (2nd ed.). USA.

McClelland, D. C. (1961). The Achieving Society. Princeton. NY: Van Nostrand. https://doi.org/10.1037/14359-000

Nunnally, J. C. (1978). Psychometric Theory. (2nd ed.). New York: McGraw-Hill.

Nwankwo, S., Hamelin, N., \& Khaled, M. (2014). Consumer Values, Motivation and Purchase Intention For Luxury Goods. Journal of Retailing and Consumer Services, 21, 735-744. 
https://doi.org/10.1016/j.jretconser.2014.05.003

Odabaşı, Y., \& Barış, G. (2011). Tüketici Davranışı. İstanbul: MediaCat Akademi.

Okada, E.M. (2005). Justification Effects on Consumer Choice of Hedonic and Utilitarian Goods. Journal of Marketing Research, 42(1), 43-53. https://doi.org/10.1509/jmkr.42.1.43.56889

Phau, I. \& Prendergast, G. (2000). Consuming luxury brands: The Relevance of The Rarity Principle. Journal of Brand Management, 8(2), 122-138. https://doi.org/10.1509/jmkr.42.1.43.56889

Phau, I. Y., \& Cheong, E. N. (2009). How Young Adult Consumers Evaluate Diffusion Brands: Effects of Brand Loyalty and Status Consumption. Journal of International Consumer Marketing, 21(2), 109-123. https://doi.org/10.1080/08961530802153185

Report, Bain \& Company. (2016). Luxury Goods Worldwide Market Study. Fall-Winter. Retrieved from http:/www.bain.com/publications/articles/luxury-goods-worldwide-market-study-fall-winter-2016.aspx

Report, D. (2015). Global Powers of Luxury Goods 2015. Engaging the Future Luxury Consumer.

Roy, R., \& Sharon, N. G. (2012). Regulatory Focus and Preference Reversal Between Hedonic and Utilitarian Consumption. Journal of Consumer Behaviour, 11, 81-88. https://doi.org/10.1002/cb.371

Ryu, K., Han, H., \& Jang, S. (2010). Relationships among Hedonic and Utilitarian Values, Satisfaction and Behavioral Intentions in the Fast-Casual Restaurant Industry. International Journal of Contemporary Hospitality Management, 22(3), 416-432. https://doi.org/10.1108/09596111011035981

Sekora, J. (1977). Luxury. The Concept in Western Thought, Eden to Smollett. London: John Hopkins University Press.

Sherry, J. F. (1990). A Sociocultural Analysis of a Midwestern American Flea Market. Journal of Consumer Research, 17, 13-30. https://doi.org/10.1086/208533

Sheth, J. N., Newman, B. I., \& Gross, B. L. (1991). Why We Buy What We Buy: A Theory of Consumption Values. Journal of Business Research, 22, 159-170. https://doi.org/10.1016/0148-2963(91)90050-8

Shukla, P. (2010). Status Consumption in Cross-National Context: Socio-Psychological, Brand and Situational Antecedents. International Marketing Review, 27(1), 108-129. https://doi.org/10.1108/02651331011020429

Shukla, P. (2012). The Influence of Value Perceptions on Luxury Purchase Intentions in Developed and Emerging Markets. Int. Market. Rev., 29(6), 574-596. https://doi.org/10.1108/02651331011020429

Shukla, P., \& Purani, K. (2012). Comparing The Importance of Luxury Value Perceptions in Cross-National Contexts. Journal of Business Research, 65(10), 1417-1424. https://doi.org/10.1108/02651331011020429

Siegel, C. F. (1996). Marketing; Foundations and Applications. Chicago: Irwin Mirror Press.

Smith, J. B., \& Colgate, M. (2007). Customer Value Creation: a Practical Framework. Journal of Marketing Theory and Practice, 15(1), 7-23. https://doi.org/10.2753/MTP1069-6679150101

Solomon, M. R. (2007). Consumer Behavior. Upper Saddle River, New Jersey: Prentice Hall.

Sombart, W. (2013). Aşk, Lüks ve Kapitalizm. Ankara: Pharmakon.

Souiden, N., M'Saad, B., \& Pons, F. (2011). A Cross-Cultural Analysis of Consumers' Conspicuous Consumption of Branded Fashion Accessories. Journal of International Consumer Marketing, 23, $329-343$. https://doi.org/10.1080/08961530.2011.602951

Stoel, L., Wickliffe, V., \& Lee, K. H. (2004). Attribute Beliefs and Spending as Antecedents to Shopping Value. Journal Business Research, 57, 1067-1073. https://doi.org/10.1016/S0148-2963(03)00016-X

Sun, M. W. (2011). Consumption of Luxury Fashion Brands: The Motives of Generation Y Consumers in China. Master of Business Thesis, Auckland University of Technology.

Sütütemiz, N., \& Kurnaz, A. (2016). Investigation of Luxury in Terms of Perception of Different Income Groups in Turkey. Journal of Administrative Sciences, 14(28), 651-671.

Tellis, G. J., \& Gaeth, G. J. (1990). Best Value, Price-Seeking, and Price Aversion: The Impact of Information and Learning on Consumer Choices. Journal of Marketing, 54(2), syf, 34-45. https://doi.org/10.2307/1251868

Tsai, S. (2005). Impact of Personal Orientation on Luxurybrand Purchase Value: An International Investigation. International Journal of Market Research, 47(4), 429-454. 
Turunen, L. L. M. (2015). Challenging The Hierarchical Categorization of Luxury Fashion Brands. NJB, 64(2), 119-138.

Turunen, L. L. M. (2015). Consumers' Experiences of Luxury-Interpreting the Luxuriousness of a Brand. Doctoral Thesis. Business Administration. Marketing. University of Vaasa.

Turunen, L. L. M., \& Laaksonen, P. (2011). Diffusing The Boundaries Between Luxury and Counterfeits. The Journal of Product and Brand Management, 20(6), 468-474. https://doi.org/10.1108/10610421111166612

Tynan, C., McKechnie, S., \& Chhuon, C. (2010). Co-Creating Value for Luxury Brands. Journal of Business Research, 63(11), 1156-1163. https://doi.org/10.1016/j.jbusres.2009.10.012

Veblen, T. (1899). The Theory of The Leisure Class. New American Library, New York.

Veblen, T. (2005). Aylak Sinıfin Teorisi. 1. Bask1 İstanbul: Babil Yayınları.

Vickers, J. S., \& Renand, F. (2003). The Marketing of Luxury Goods: An Exploratory Study. Three Conceptual Dimensions. Market Rev., 3(4), 459-484. https://doi.org/10.1362/146934703771910071

Vigneron, F., \& Johnson, L. W. (1999). A Review and A Conceptual Framework of Prestige-Seeking Consumer Behavior. Academy of Marketing Science Review, 1, 1-15.

Vigneron, F., \& Johnson, L. W. (2004). Measuring Perceptions of Brand Luxury. Journal of Brand Management, 11, 484-506. https://doi.org/10.1057/palgrave.bm.2540194

Voss, K. E., Spangenberg, E. R., \& Grohmann, B. (2003). Measuring the Hedonic and Utilitarian Dimensions of Consumer Attitude. Journal of Marketing Research, 40(3), 310-320. https://doi.org/10.1509/jmkr.40.3.310.19238

Westbrook, R. A., \& Black, W. (1985). A Motivation-Based Shopper Typology. Journal of Retailing, 61, 78-103.

Wiedmann, K. P., Hennigs, N., \& Siebels, A. (2007). Measuring Consumers' Luxury Value Perception: A Cross-Cultural Framework. Academy of Marketing Science Review, 7, 1-21.

Wiedmann, K. P., Hennigs, N., \& Siebels, A. (2009). Value Based Segmentation of Luxury Consumption Behavior. Psychology \& Marketing, 26, 625-651. https://doi.org/10.1002/mar.20292

Yeo, J., \& Park, J. (2006). Effects of Parent-Extension Similarity and Self Regulatory Focus on Evaluations of Brand Extensions. Journal of Consumer Psychology, 16(3), 272-282. https://doi.org/10.1207/s15327663jcp1603_9

\section{Copyrights}

Copyright for this article is retained by the author, with first publication rights granted to the journal.

This is an open-access article distributed under the terms and conditions of the Creative Commons Attribution license (http://creativecommons.org/licenses/by/4.0/). 